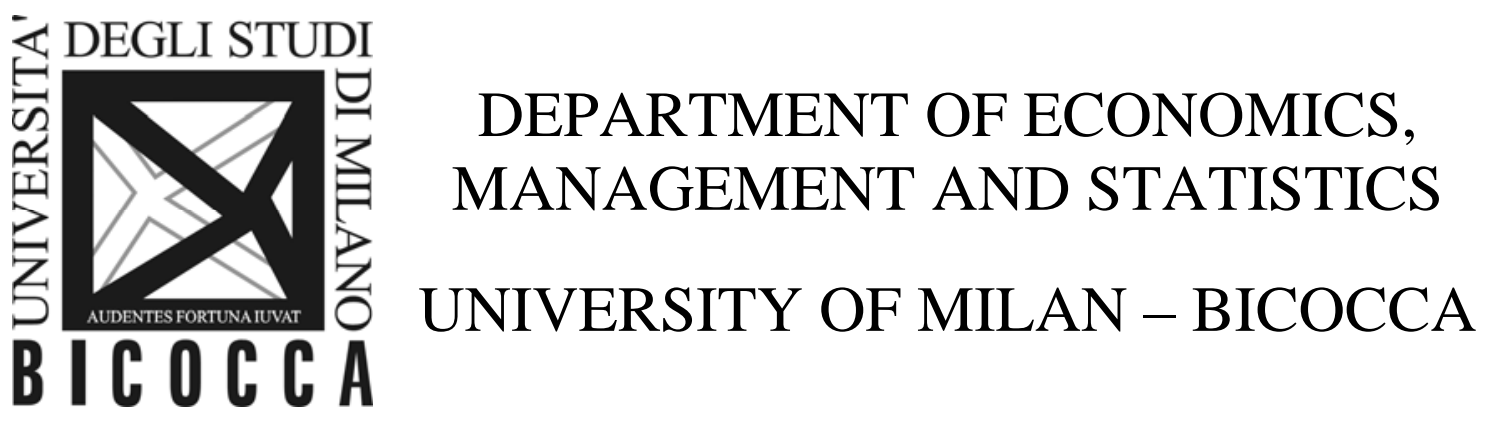

DEMS WORKING PAPER SERIES

\title{
The Dragon and the Elephant on the way to Italy
}

Valeria Gattai

No. 248 - June 2013

Dipartimento di Economia, Metodi Quantitativi e Strategie di Impresa Università degli Studi di Milano - Bicocca

http://dems.unimib.it/ 


\title{
The Dragon and the Elephant on the way to Italy
}

\author{
Valeria Gattai*
}

\begin{abstract}
This paper provides original evidence about Chinese and Indian Outward Direct Investment in Italy. Firm-level data have been collected through survey interviews involving the whole population of Dragon and Elephant multinationals. With a response rate of $80 \%$, we draw a detailed profile of the parent companies and investigate their main drivers, entry modes, and satisfaction with the local operations.
\end{abstract}

Keywords: outward direct investment, India, China, Italy

JEL: F23, O53

\footnotetext{
* Università degli Studi di Milano-Bicocca, Dipartimento di Economia, Metodi Quantitativi e Strategie di Impresa. The author is grateful to Gianmarco Ottaviano and Roberta Rabellotti for their useful comments and insightful discussions, Alessandro Durì, Francesca Ghezzi, Jennifer Molinari, Alessio Paternoster and Valentina Zanatta for their valuable assistance in data collection. This paper is part of the project "Chinese Investments in Europe". Financial support from CASCC and Chatham House is gratefully acknowledged. All remaining errors are the author's own.
} 


\section{Introduction}

Recent years have witnessed the emergence of a new geography of Foreign Direct Investment (FDI) in which developing countries play a prominent role as home, adding to host markets $^{1}$ (Goldstein, 2006; UNCTAD, 2006; Mariotti and Mutinelli, 2007, 2008; Giovannetti and Mazzeo, 2008; Mariotti, 2009).

In this context, China ${ }^{2}$ and India figure out as leading global investors, due to the impressive growth rate of their outward FDI that tops 470 bln USD nowadays (UNCTAD, 2012). With outflows equal to 65 bln USD in 2011, China ranks $9^{\text {th }}$ among the largest source countries worldwide, and $2^{\text {nd }}$ among developing countries; with outflows equal to 15 bln USD, India is the $24^{\text {th }}$ largest investor in the world, and the $7^{\text {th }}$ among emerging economies (UNCTAD, 2012). Hence, the Dragon and the Elephant, traditionally considered as a destination for foreign direct investment, are increasingly becoming a source of multinational activity.

As shown in Figure 1, Chinese and Indian Outward Direct Investment (ODI) is a recent phenomenon that takes place only in the last few decades as a consequence of massive government intervention to promote globalization and growth (Athukorala, 2009; Singh and Jain, 2009; Yueh, 2010; Wei and Wang, 2009; Zhang and Liu, 2009). However, its rise is fast and dynamic: starting from virtually 0 ODI in 1990, China reaches the record stock of 365 bln USD in 2011, and India tops 111 bln USD during the same year. If we further dissect this evidence by country of origin, we see that the Dragon has a stronger attitude towards ODI, since Chinese internationalization occurs earlier, and volumes of outward direct investments remain larger for the entire period 1990-2011.

On the contrary, if we look at the international network wideness and deepness, Indian multinationals reveal a better positioning than the Chinese ones, with more than 4500 subsidiaries worldwide ${ }^{3}$. As for the geographical distribution, affiliates tend to cluster around North America, Asia and the European Union that account for $80 \%$ of total FDI from the two countries (Figure 2). As a matter of fact, the Elephant and the Dragon

\footnotetext{
${ }^{1}$ Consistently with the IMF/OECD definitions, we call FDI an investment in a foreign company in which the investor owns at least 10 percent of the ordinary shares, undertaken with the objective of establishing a lasting interest in the country, a long-term relationship, and a significant influence on the management of the firm (IMF, 1993; OECD, 1996). In our terminology, multinational enterprises are those engaged in foreign direct investment. Moreover, "developing” and "emerging" economies are treated as synonymous.

${ }^{2}$ In this paper, “China” denotes the so called "Mainland China”, without Hong Kong and Taiwan.

${ }^{3}$ For more information regarding the globalness of Indian MNEs, see Pradhan and Aggarwal (2011).
} 
prefer to invest in advanced (US, EU and Canada) or nearby (Asia) economies; moreover, Chinese FDI is directed primarily towards Asia, while Indian MNEs operate in North America the most. Across the broad array of feasible hosts, the European Union plays an important role as well, attracting $11 \%$ of Chinese and $26 \%$ of Indian foreign direct investments.

Figure 1: Chinese and Indian Outward FDI stocks, 1990-2011, bln USD

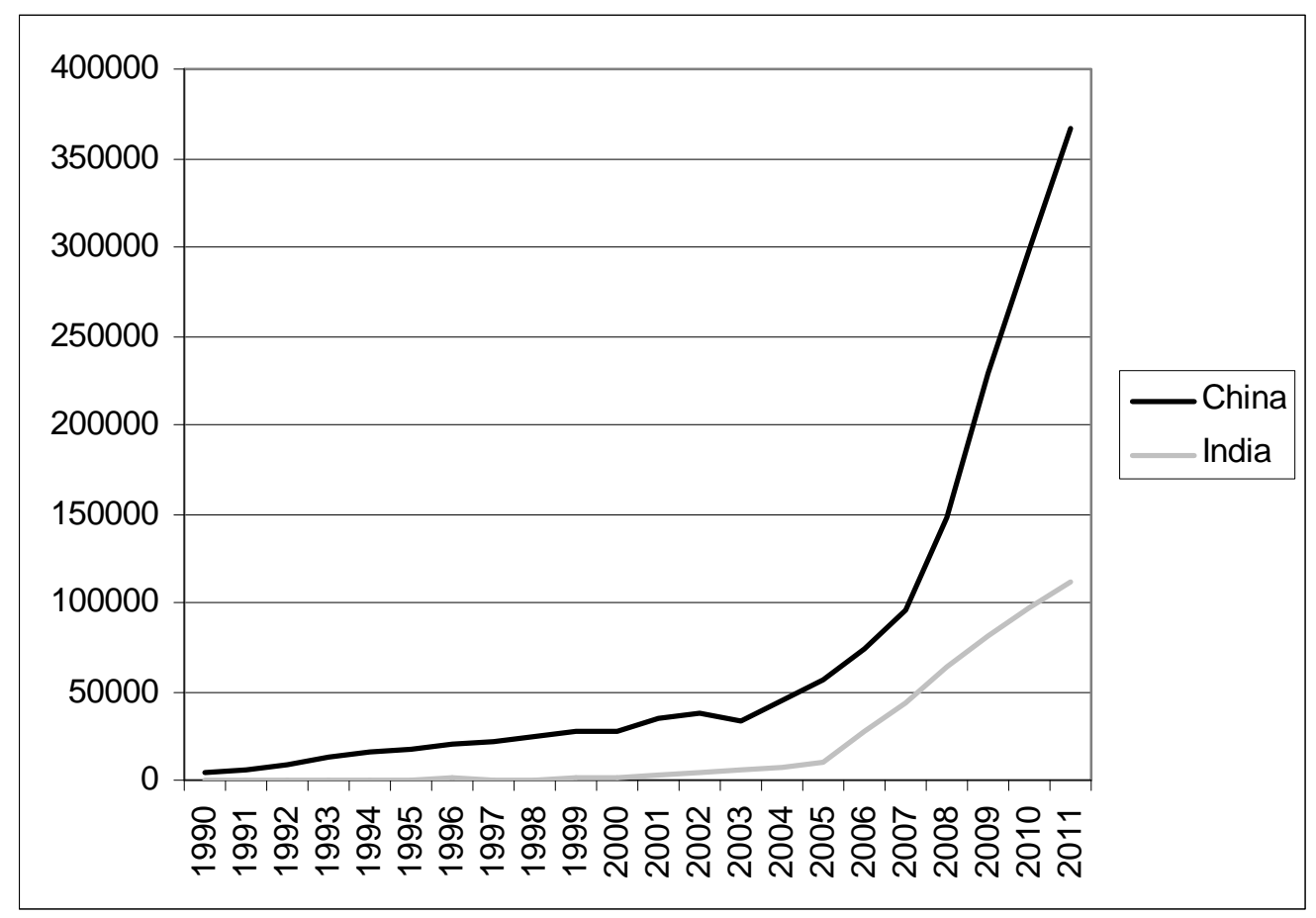

Source: author's elaborations from UNCTAD (2012)

Within Europe, Italy is the $4^{\text {th }}$ major recipient of Chinese and Indian FDI, after UK, Netherlands and Germany; in particular, it ranks $3^{\text {rd }}$ among the most frequent destinations of Chinese Multinational Enterprises (MNEs) and $6^{\text {th }}$ among Indian most preferred host countries (Orbis, 2012). This suggests that the Dragon and the Elephant are on the way to Italy.

In light of the above discussion, the present paper investigates Chinese and Indian ODI in the Italian market, providing original evidence on the topic. Data come from a multiple-choice questionnaire designed by the author and submitted to the whole population of Chinese and Indian affiliates between 2010 and 2012. With a response rate of $80 \%$, we outline the quantitative and qualitative features of 50 direct investments, making quite a new and detailed picture. 
In particular, we ask: Who are Chinese and Indian investors in Italy? What drives their ODI? Which entry mode do they select? How do they evaluate the Italian experience? Our data allow us to answer these and similar questions, considering both the overall sample, including Chinese and Indian respondents, and the two sub-samples from individual countries.

Figure 2: Geographical distribution of Chinese and Indian outward FDI, 2011, number of foreign affiliates

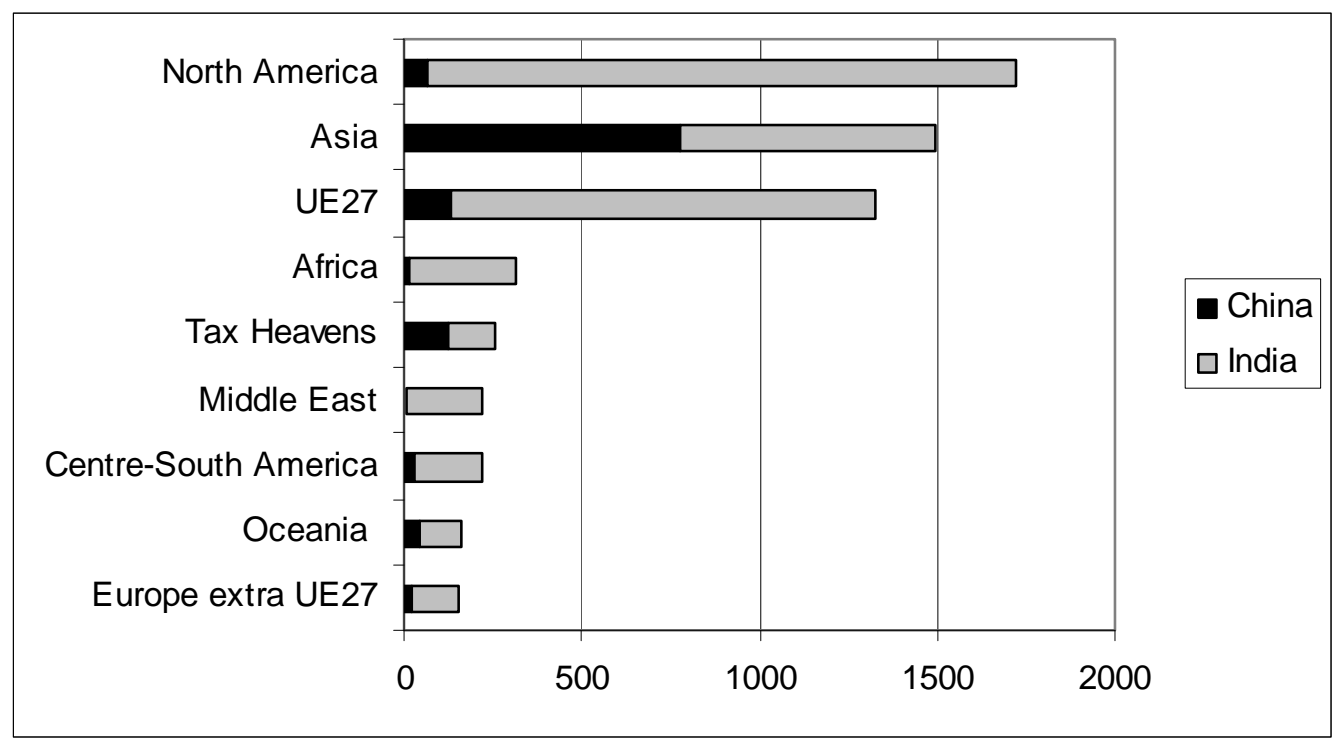

Source: author's elaborations from Orbis (2012)

If the choice of the topic positions our contribution within the burgeoning literature on emerging economies $\mathrm{ODI}^{4}$, we depart from the existing studies in many regards. First, this is a quantitative analysis, while most papers investigating Dragon and Elephant multinationals are qualitative, with lots of interesting questions but no definite answers (see, among others: Child and Rodrigues 2005; Deng, 2007; Kumar, 2008; Nicholas, 2009; Ramapurti and Singh, 2009; Niosi and Tschang, 2009). Second, we take a micro rather than a macro perspective, differently from the majority of (the few) empirical studies on the topic that only provide a general overview of sector and geographical patterns (see, for instance: Schuller and Turner, 2005; Goldstein, 2006; Nicolas and Thomsen, 2008; Rabellotti and Sanfilippo, 2008; Stanca, 2009; Rajian, 2009; Singh and Jain, 2009). Third, we employ original survey data, instead of anecdotal evidence, case

\footnotetext{
${ }^{4}$ For a survey see Amighini et al. (2009b).
} 
histories or sector analysis that fully exhaust ${ }^{5}$ previous microeconomic treatment of emerging economies ODI (see, for instance: Kumar and Chada, 2009; Duysters et al., 2009; Spigarelli, 2009; Pietrobelli et al., 2010). Last but not least, to the best of our knowledge, this is the first empirical attempt at comparing Chinese and Indian ODI, giving protagonists direct voice on their overseas experience ${ }^{6}$. For all these reasons, the present paper should be considered as highly complementary to the previous ones, completing their perspective through the micro view, and enriching their results with survey data.

At the same time, we are aware of some limitations that should be carefully considered in evaluating our empirical findings. Indeed, despite the high response rate, the limited number of observations prevents us from conducting a proper econometric exercise; therefore, results are summarized through summary statistics and figures ${ }^{7}$. Moreover, the single-host/double-home nature of the analysis makes this study highly specific; so, we resist from generalizing results too much, and simply consider the present exercise as a first step in dissecting Chinese and Indian ODI at the micro level.

The rest of the paper is organized as follows. Section 2 provides a brief literature review on emerging countries ODI, as a conceptual framework for the empirical analysis. Section 3 is entirely devoted to the survey methodology and results, with particular attention at the matching between empirical findings and theoretical expectations. Section 4 then concludes and sets future lines of research.

\section{Literature review}

In what follows, we review the main contributions about emerging countries ODI, organized according to the research questions, raised in Section 1.

\footnotetext{
${ }^{2} \mathrm{~A}$ few exceptions are due to Buckley et al. (2008a), Cui et al. (2008) and Zhang (2005). Buckley et al. (2008a) captures $17 \%$ of Chinese ODI in the UK by means of a brief questionnaire, focused only on strategic drivers. Cui et al. (2008) complements micro data from the Statistical Bullettin of China's Outward Foreign Direct Investment, through questions about entry mode choices. Zhang (2005) interviews over 200 Chinese enterprises (not necessarily MNEs) to state their potential interest in investing in Canada. Compared with these papers, our takes a more accurate picture, due to the wider spectrum of topics included in the survey, the larger number of questions posed to the investors, and the higher response rate, that allow us to characterize the entire population. Moreover, considering both Chinese and Indian MNEs, this study allows for interesting comparisons among the two home countries.

${ }^{6}$ Milelli and Hay (2008) take a similar perspective, investigating Dragon and Indian FDI in Europe at the firm-level. However, the lack of information regarding their empirical methodology (questionnaire, population, sample, country coverage) makes their study hardly comparable with the present one.

${ }^{7}$ Unfortunately we cannot provide any explicit example since the surveyed enterprises asked to remain anonymous. Anecdotal evidence of this sort can be found in Spigarelli (2009) and Pietrobelli et al. (2010), limitedly to the Chinese case.
} 


\subsection{Characteristics of emerging countries multinationals}

As far as the portrait of emerging countries MNEs is concerned, many authors identify some typical features - in terms of size, industry, and type of ownership - that help characterize the representative investor.

According to Amighini et al. (2009b) and UNCTAD (2006), multinational enterprises from developing countries are usually large companies, enjoying a leading global position in industries such as automotives, chemicals, electronics, petroleum refining and steel, transport and telecommunication. Moreover, they are used to operating in highly volatile environments (Fortanier and Tulder 2009), and they enjoy a high degree of state ownership, which explains the active role played by the government in promoting their global expansion (Athukorala, 2009; Singh and Jain, 2009; Yueh, 2010; Wei and Wang, 2009; Zhang and Liu, 2009; Yeung and Liu, 2008).

If emerging economies multinationals are usually treated as a homogeneous group, visà-vis advanced economies MNEs, Duysters et al. (2009), Niosi and Tschang (2009) and Kumar and Chadha (2009) explore cross-country differences between Chinese and Indian players. In particular, they find that firms from both countries receive notable state support, they are successful in creating new products and accessing new markets and make strategic asset seeking ODI. Nonetheless, Indian investors have a much longer history, a stronger preference for merger \& acquisitions and they are used to targeting developed markets only after several decades of experience in developing countries, compared with their Chinese counterparts.

\subsection{Motivations behind emerging countries ODI}

Having summarized some typical features of emerging countries multinationals, in this subsection we discuss the main motivations underlying their ODI.

Building on the seminal contribution of Dunning (1993), outward direct investments from advanced countries are traditionally explained as an attempt to capitalize abroad certain Ownership-Location-Internalization (OLI) advantages, owned before internationalization. Whether this "traditional view" on FDI is applicable to investment projects from emerging economies is still under debate.

A first group of authors criticizes Dunning's approach, claiming that the OLI theory has only limited power in interpreting developing countries ODI. This is because multinational enterprises from emerging economies generally lack the kind of 
advantages that the theory denotes as a prerequisite for investing abroad. So, they engage in asset-seeking rather than asset-exploiting FDI, expanding overseas to access key resources that they were not able to secure domestically (Deng 2007; Luo and Tung 2007; Athreye and Kapur 2009; Child and Rodrigues 2005; Zhang 2005; Buckley et al. 2007).

A second group of papers allows only for a modest reconsideration of the traditional view, showing that the old theory can be adapted to explain developing countries direct investments. For instance, through a longitudinal cross-country comparative study of 256 large firms for the period 1990-2005, Fortanier and Tulder (2009) find that Chinese and Indian multinationals are not a completely new species of firms. Indeed, the OLI mechanism is still at work because they possess some ownership advantages, even though different from those of developed countries. While investors from advanced economies traditionally rely on human capital, reputation and technology, their counterparts from emerging areas rely on process capabilities, management and corporate entrepreneurship, parental networks, flexibility, social and networking skills (Fortanier and Tulder 2009; Yiu et al. 2007; Buckley et al. 2007; UNCTAD 2006).

Despite the different positions on the applicability of Dunning's view to emerging economies ODI, a variety of drivers seems to promote the global expansion of developing countries MNEs. They can be divided into pull and push factors: the former include market-, resource-and efficiency-seeking considerations (Athreye and Kapur 2009; Fortanier and Tulder 2009; Duysters et al. 2009; Nicolas 2009; Yeung and Liu 2008; Milelli and Hay 2008; Deng 2007; Schuller and Turner 2005; Zhang 2005), while the latter range from government support to the availability of capital to invest and the over-capacity in the domestic market (Kumar and Chadha 2009; Athreye and Kapur 2009; Duysters et al. 2009; Berger and Berkofsky 2009; Nicolas 2009; Nicolas and Thomsen 2008; Milelli and Hay 2008; Yeung and Liu 2008; Deng 2007; Schuller and Turner 2005).

\subsection{Entry modes of emerging countries ODI}

As far as the entry mode is concerned, latecomer multinationals tend to operate abroad via Joint Venture (JV), Merger \& Acquisition (M\&A) or Wholly Foreign-Owned Enterprises (WFOEs) (Nicolas 2009; Nicolas and Thomsen 2008; Deng 2007; Child and Rodrigues 2005; Schuller and Turner 2005). 
The first case identifies partnerships between foreign and local enterprises. They usually base on complementary skills between the two parties, and have a limited length of time. Under a joint venture agreement, by definition, the parent company has only partial ownership of the local affiliate.

The second case applies to instances in which the foreign investor acquires or merges with a local enterprise. Ownership may be partial or total depending on the percentage of foreign acquisition. Notice, however, that partial acquisition differs from joint venture from a legal point of view, because it does not imply the birth of a new enterprise, but rather a reallocation of resources under the parent company.

Finally, the case of wholly-owned enterprise consists of a $100 \%$ foreign direct investment, under which total ownership of the local affiliate rests with the multinational. Even if a WFOE may be the result of a greenfield investment or a full acquisition, the literature about emerging countries ODI tends to identify it with the former. Therefore, most contributions compare three entry modes, namely JV, WFOE, and M\&A, instead of restricting attention to partial versus full ownership of the local affiliate.

As mentioned in Amighini at al. (2009), past Chinese FDI was usually carried on via WFOE and it was directed towards emerging economies. Contrary to this, recent operations are mainly based on M\&A and JV and they concentrate in advanced countries. This pattern is probably related to the type of ownership and the pull factors. Indeed, over the 1990s, the main protagonists of Chinese ODI were large state-owned enterprises, enjoying massive government support and expanding abroad for (natural) resource-seeking motivations. Hence, they targeted developing countries the most and decided to operate alone. One decade later, this scenario dramatically changed, and many private enterprises entered into the world stage, responding to competitive pressures and market stimulus. This is the type of investors that expand abroad due to over-capacity in the domestic market or availability of capital to invest and make (strategic) resource-seeking FDI. As a result, these players usually enter into developed countries through M\&A or JV, to maximize potential links with local enterprises and overcome their liability of emergingness (Madhok and Keyhani 2012). 


\section{Empirical analysis}

\subsection{Data}

The present study builds on a comprehensive survey conducted by the author between 2010 and 2012 and involving the entire population of Chinese and Indian affiliates in Italy. All firms were contacted by phone, and then a multiple-choice questionnaire was submitted by email (70\%) or fax (30\%) to senior managers and CEOs. In some cases, the local affiliate also forwarded our material to the parent company to provide more detailed answers and reliable data. The questionnaire is made up of two sections: first we ask background information about the parent company, including balance sheet details, intangible assets and international experience; second, we investigate some strategic drivers behind their ODI, such as motivations, entry modes, and overall evaluation of the local experience. This helps provide an empirically documented answer to the questions raised in Section 1.

The original list of investors was obtained through a number of sources, such as the ICE-Reprint database ${ }^{8}$, ORBIS, Amighini et al. (2009a) and Spigarelli (2009) ${ }^{9}$. More precisely, the ICE-Reprint database provides micro-level information about inward and outward FDI in Italy. As far as the inward side is concerned, it displays the contact details of the parent company, by home country, and its Italian affiliate. Adding to this, ORBIS contains comprehensive firm-level information on companies worldwide, including balance sheet details, shareholders, domestic and foreign affiliates. Finally, Amighini et al (2008) and Spigarelli (2009) provide some anecdotal evidence on Chinese FDI in Italy, displaying a list of parent companies and local subsidiaries. For our purposes, we proceeded as follows: first, through the ICE-Reprint database, we extracted a tentative list of Chinese and Indian investors in Italy, identifying 14 MNEs from the Dragon, and 25 from the Elephant. Second, we looked at ORBIS and found other 10 Chinese and 7 Indian multinationals with affiliates in the same country; third, we added 2 examples of Dragon operations mentioned in Amighini et al (2008) and 12 described in Spigarelli (2009).

By comparison and merge of all the available information, at the end of this process, we identified a population of 38 parent companies headquartered in China, and 32

\footnotetext{
${ }^{8}$ We thank Marco Mutinelli for access to the ICE-Reprint database.

${ }^{9}$ A comprehensive list of Chinese firms in Italy can be found also in Pietrobelli et al. (2010) that provide anecdotal evidence on the topic.
} 
headquartered in India, whose local affiliates were all contacted by phone. At this stage, getting rid of firms without any contact details (11 for China, 6 for India) ${ }^{10}$, already closed ( 2 for India) or not responsible for direct investments ( 6 for China, 8 for India) ${ }^{11}$, we ended up with a population of 21 investors from the Dragon and 16 investors from the Elephant. With an exceptional response rate of $80 \%$, this study documents the characteristics of 21 Chinese multinationals, running 28 affiliates in Italy, and 10 MNEs from India that are responsible for 19 FDIs.

In what follows, we present the main survey results: (3.2) makes a portrait of Chinese and Indian multinationals, (3.3) discusses the motivations behind their ODI, (3.4) focuses on entry modes decisions and (3.5) presents the overall evaluation of the local experience.

\subsection{Characteristics of Chinese and Indian multinationals}

A preliminary look at the survey responses suggests that the profile of Chinese and Indian MNEs with FDI in Italy is very diverse.

If we look at firms' age, for instance, our database exhibits a good deal of variety, encompassing both very old and very recent companies. According to the year of foundation, the oldest firm dates back to 1900 while the youngest was born in 2007. Consistently with Duysters et al. (2009), Indian MNEs tend to be older than their Chinese counterparts.

As for the type of ownership, the empirical evidence reported in Figure 3 supports by and large the theoretical expectation of Amighini and Chiarlone (2007), Yeung and Liu (2008), Niosi and Tschang (2009) and Kumar and Chada (2009) that state-owned enterprises are still the main protagonists of Chinese outward initiatives. Indeed, only $25 \%$ of Dragon multinationals is private, against the whole Indian sub-sample.

Figure 4 then displays the sector composition of the surveyed ODIs. In line with Buckley et al. (2008) and UNCTAD (2006), they mainly belong to industries such as textile, apparel and shoes (18\%), industrial machineries (17\%), electronics (14\%), transport (14\%), automobiles (11\%), telecommunications (11\%), pharmaceutical (4\%)

\footnotetext{
${ }^{10}$ The contact details displayed in the original data source were sometimes wrong or missing. In this case, we replaced them with correct ones by looking at the companies' website. So, the label "firms without any contact details" used on top of this page refers to instances in which it was actually impossible to contact the local affiliate either because its contact details were not available anywhere, or because they were not working anyhow.

${ }^{11}$ Some firms appearing in the ICE-Reprint database, ORBIS, Amighini et al. (2009a) or Spigarelli (2009) as investors are actually managing only a representative office in Italy.
} 
and motorcycles (4\%). Dissecting this evidence by country of origin allows identifying interesting differences between the Dragon and the Elephant: while the former operates in all the above mentioned sectors, with a remarkable concentration in the transport, electronics and telecommunication industries, the latter belongs only to the textile, apparel and shoes (30\%), industrial machineries (30\%), automobiles (30\%) and pharmaceutical (10\%) ones.

Figure 3: Type of ownership of Chinese and Indian investors

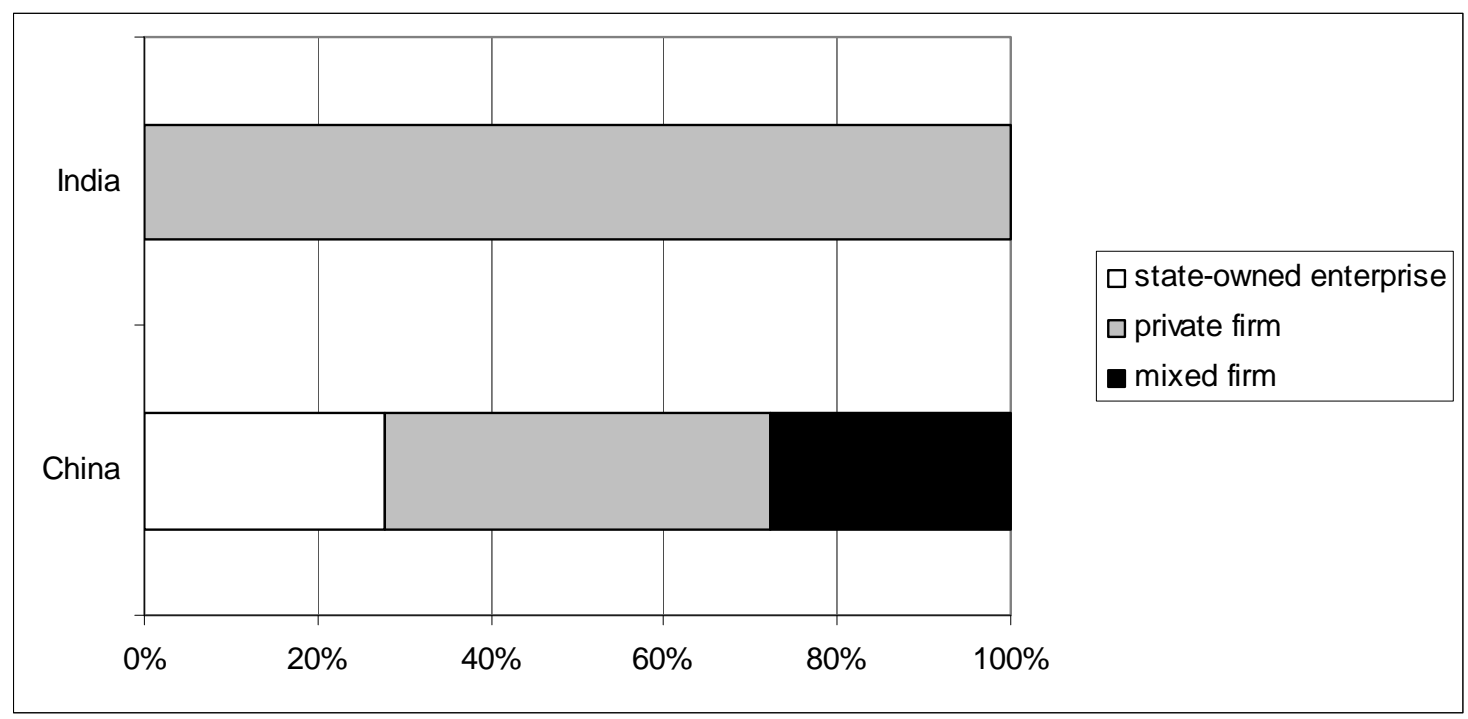

Source: author's database

As far as the host region is concerned, the sampled FDIs tend to cluster around the Centre and North of Italy, with peaks of $27 \%$ in Lombardia, $13 \%$ in Piemonte, $13 \%$ in Liguria and $8 \%$ in Veneto; Puglia is the only region in the South that attracts a notable 19\% of Chinese and Indian FDI, without any significant difference by country of origin (Figure 5). Considering the large body of literature about Italian industrial districts ${ }^{12}$, one may wonder if the geographical distribution of the sampled FDIs is somehow linked with regional clusters. To be honest, our evidence on this issue is quite mixed. As a matter of fact, Chinese and Indian investors locate in the top 10 Italian regions if we look at the number of industrial districts. Indeed, Veneto has 41, Lombardia 26, Emilia Romagna 13, Toscana 11, Piemonte 9, Marche and Campania 8, Puglia, Liguria and Friuli Venezia-Giulia 7, Lazio, Abruzzo and Sicilia 6, Sardegna and Umbria 5, Basilicata and Calabria 3, Molise and Trentino Alto-Adige 1. This would potentially allow for spillover effects due to specialized suppliers, high skilled labour force and

\footnotetext{
${ }^{12}$ See, for instance, Becattini (1998).
} 
established know-how. However, these effects are likely to materialize only if foreign investors operate in the same sector the industrial district belongs to. Our evidence suggests that this is rarely the case. As far as Chinese investments are concerned, only transport operations in Liguria and Lazio and production of home appliances and industrial machineries in Lombardia are somehow linked to regional clusters ${ }^{13}$. This is not surprising in light of our previous discussion about the sector distribution of the sampled FDIs. As mentioned above, Chinese operations mainly concentrate in the electronics, transport and telecommunication industries which are not the typical "made in Italy” activities run in the regional clusters. On the contrary, ethnic networks seem to play a more important role in attracting FDI, since the geographical distribution of Chinese affiliates shows a clear concentration where there is a well established Chinese community. As for the Indian investments, potential links between foreign operations and regional clusters are a bit easier since they belong to the textile, apparel and shoes sector the most, which is a typical "made in Italy" segment. Yet, production of textiles and industrial machineries in Piemonte by Indian enterprises is closely related with local industrial districts.

Figure 4: Sector distribution of Chinese and Indian investors in Italy

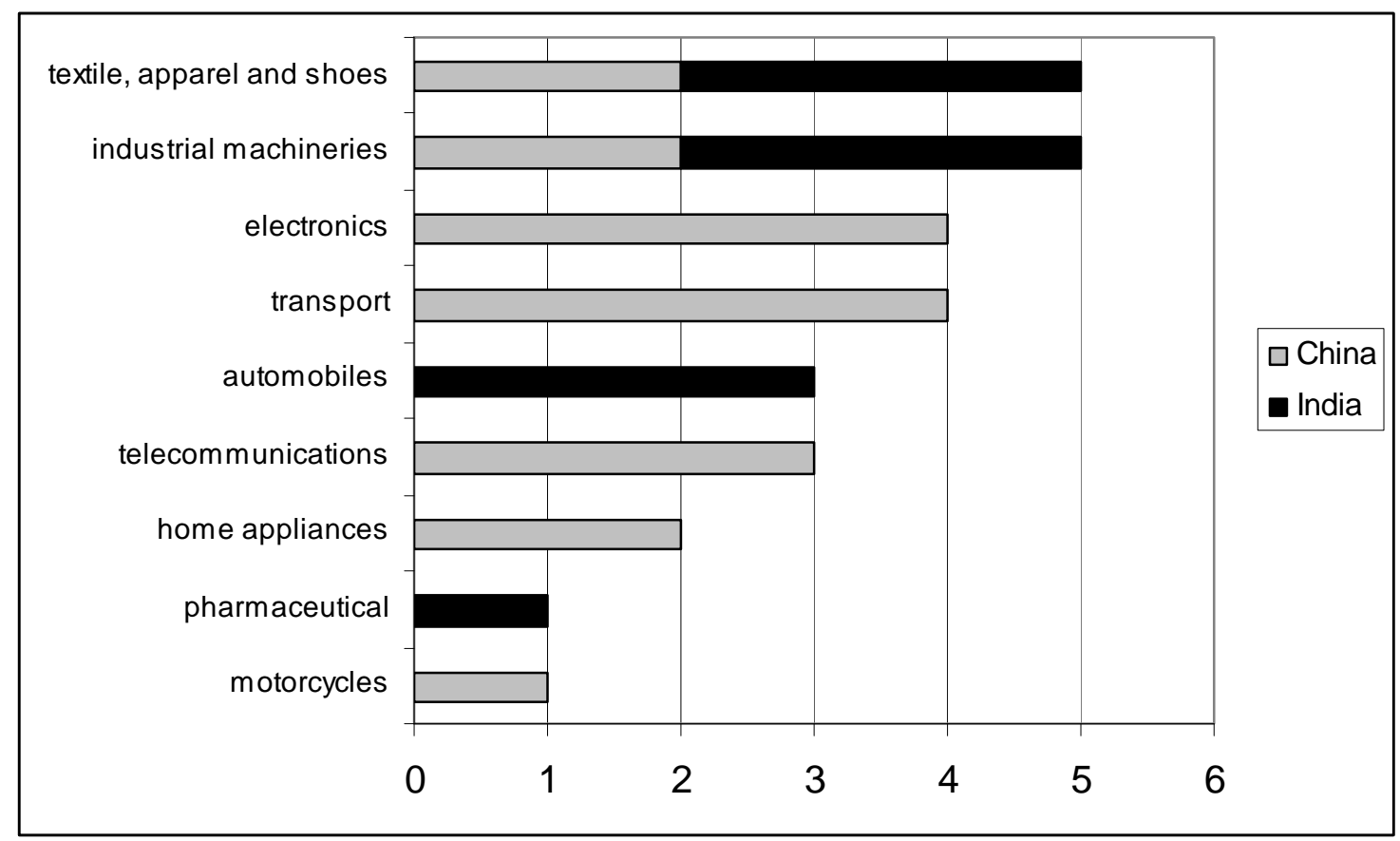

Source: author's database

${ }^{13}$ On this issue, see also Pietrobelli et al. (2010). 
Figure 5: Geographical distribution of Chinese and Indian investors in Italy

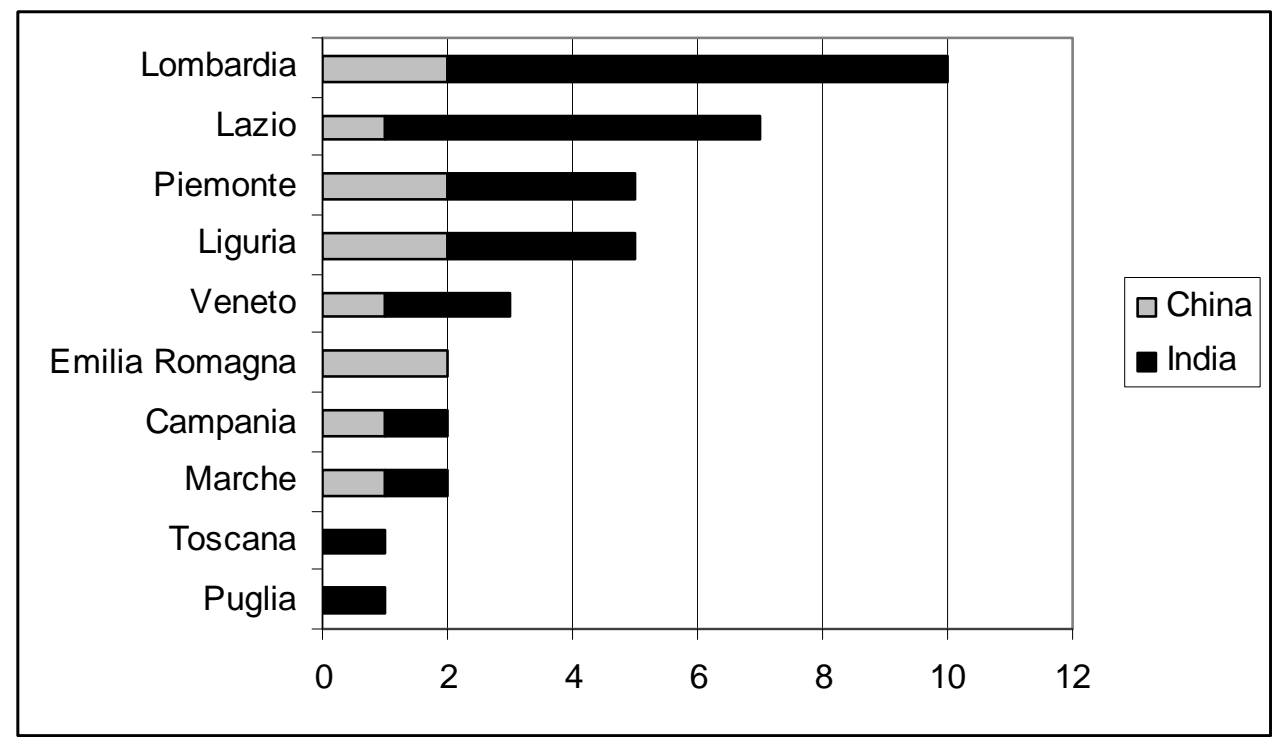

Source: author's database

In terms of firms' size, Dragon and Elephant multinationals tend to be very large companies, with number of employees between 1000 and 220000. To be more precise, Chinese MNEs are usually larger, with average employment of 40000 units, against 20000 employees of the Indian representative firm. Similar results emerge in terms of sales, far exceeding 500000 euro for the sample as a whole. Chinese average sales equal 6 billion euro, Indian ones are about 2 billion euro, consistently with the theoretical framework due to Amighini et al. (2009b) and UNCTAD (2006), where large size is denoted as a typical characteristic of emerging countries MNEs.

Not surprisingly, large size matches a huge amount of invested capital in most cases. As shown in Figure 6, for 70\% of the respondents, the overall investment in Italy exceeds 1 million euro. Notice also that Indian parent companies invest more than their Chinese counterparts, contradicting the general wisdom reported in Figure 1. Put another way, even though Chinese volumes of ODI worldwide are more consistent than the Indian ones, limitedly to the Italian case, the opposite occurs. In fact, the percentage of investments larger than 1 million euro is $85 \%$ for the Elephant, 60\% for the Dragon.

The questionnaire also explores human capital, technology and international experience of Chinese and Indian parent companies. Human capital is proxied by the percentage of employees holding a degree, which is equal to $30 \%$ on average, and reaches a maximum of $90 \%$ for the Dragon, and $60 \%$ for the Elephant. Differently from human capital, 
technology is quite modest, with average $R \& D$ investments equal to $7 \%$ of sales, and never exceeding 20\%, throughout the whole sample.

Figure 6: Chinese and Indian investments in Italy

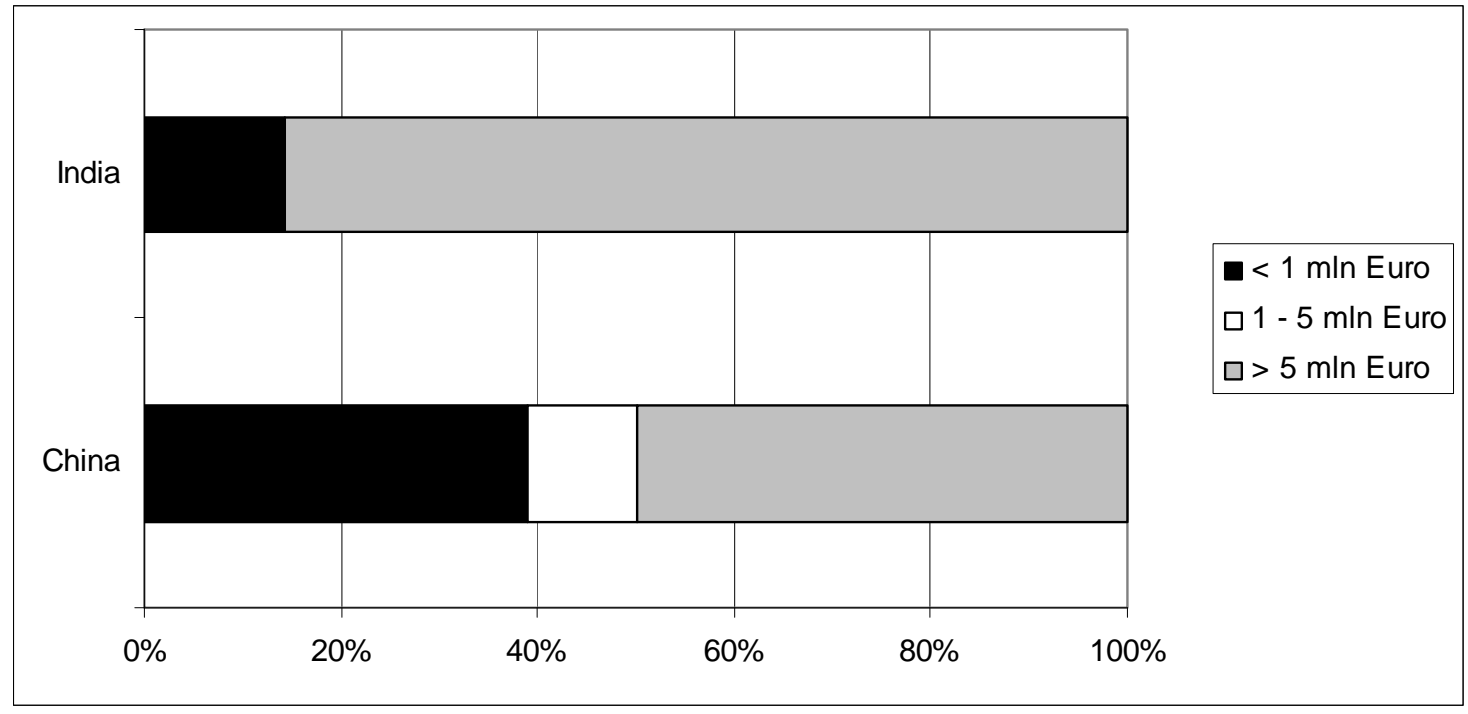

Source: author's database

As far as the international experience is concerned, our data confirm Kumar and Chada (2009), Niosi and Tschang (2009) and Duysters et al. (2009) in that export over sales is usually very high, especially for India, where it tops 70\%. Figures 7 and 8 investigate this issue more deeply by looking at the type of international business, if any, established with European (Figure 7) and Italian (Figure 8) enterprises before the current FDI. As a matter of fact, Chinese and Indian direct investments usually ground on a good deal of experience in managing foreign operations. Indeed, $80 \%$ of the sample had some contacts with European firms before investing in Italy. These contacts range from import-export (30\%) to FDI (23\%), from franchising (10\%) to licensing $(10 \%)$ and representative offices (6\%). Controlling for the country of origin, again, Indian MNEs turn out to be more experienced than the Chinese ones and they exhibit a stronger attitude towards FDI. Indeed, more than 90\% of the Indian sub-sample had established some type of international business in Europe before the current investment in Italy (74\% in the Chinese case), and half of that was running FDI (11\% in the Chinese case).

If we narrow down our perspective and zoom on Italy, rather than Europe, these values tend to fall. In particular, half of the sampled multinationals had consolidated some business in Italy before their current involvement, and FDI looks definitely less frequent 
than import-export (33\%), licensing (7\%) and franchising (7\%). Last but not least, Indian direct investments tend to be more recent than the Chinese ones: if the Dragon has opened its first subsidiaries in Italy in the late 1990s, the Elephant has followed only one decade later.

Figure 7: Chinese and Indian investors' experience in Europe before the current FDI in Italy

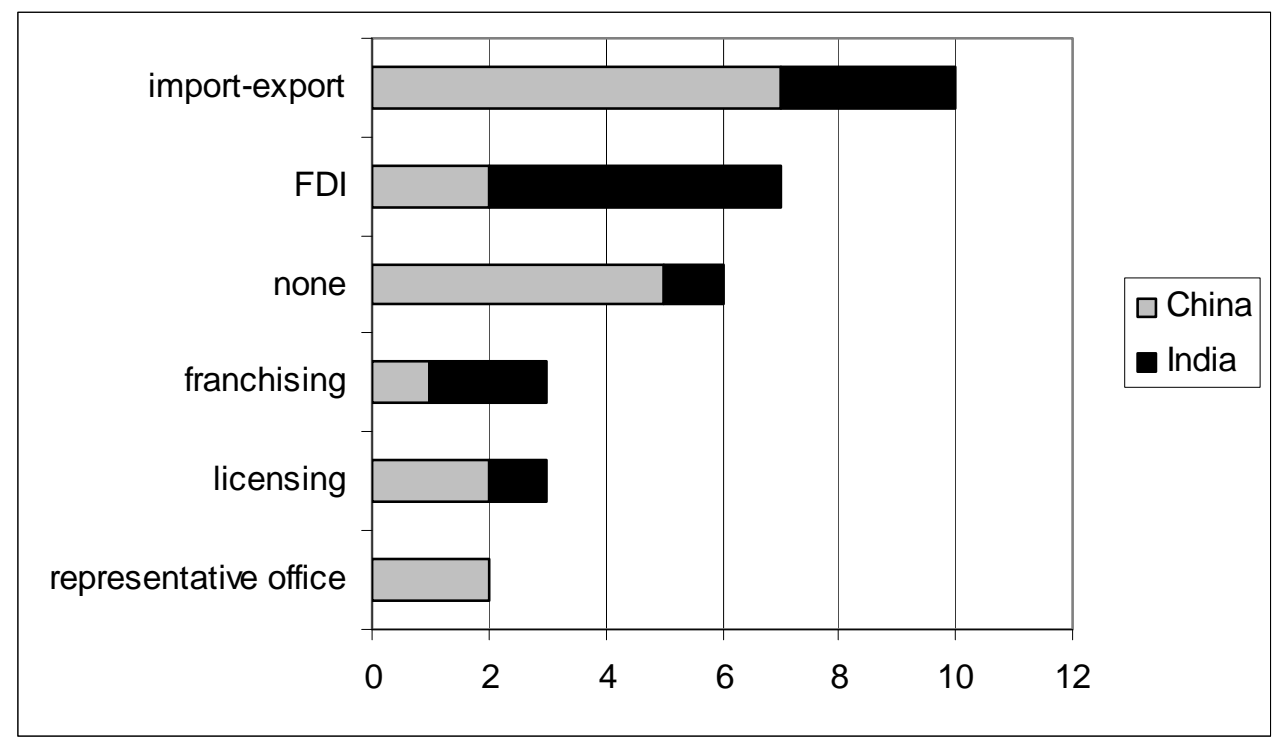

Source: author's database

Figure 8: Chinese and Indian investors' experience in Italy before the current FDI

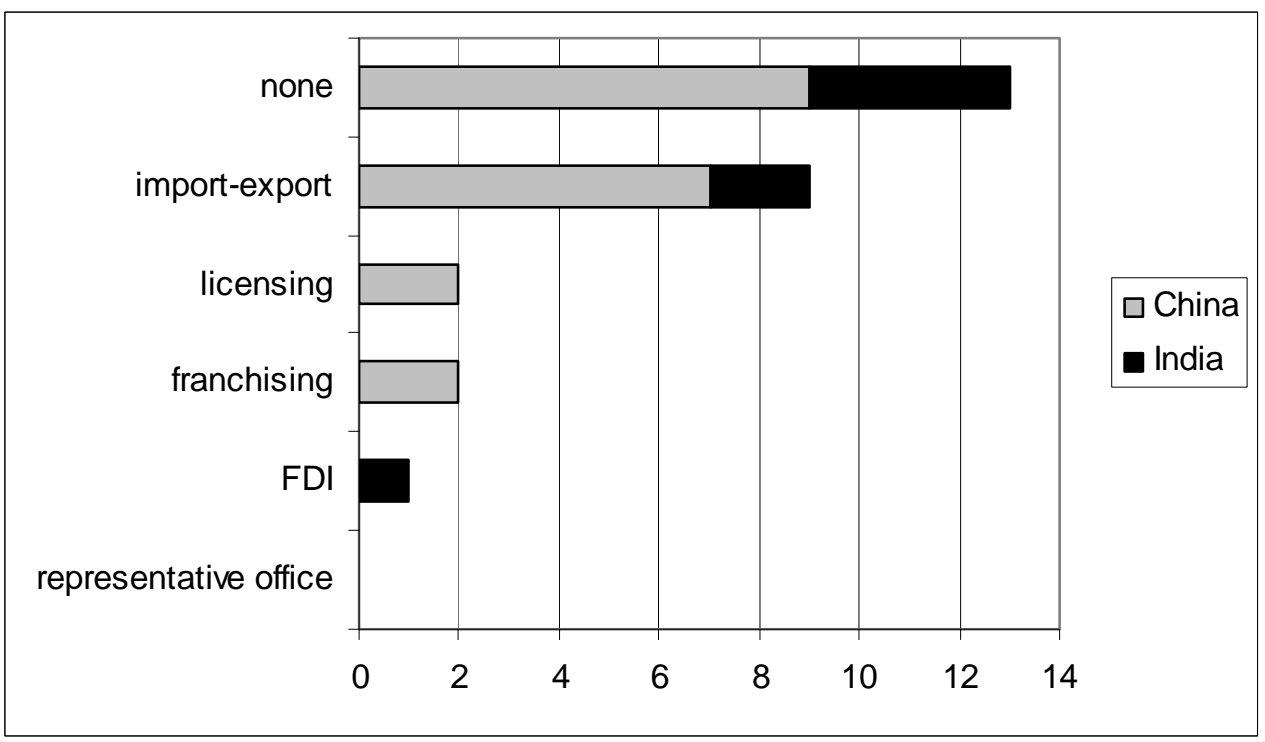

Source: author's database 


\subsection{Motivations behind Chinese and Indian ODI}

Having briefly described the characteristics of Chinese and Indian MNEs, we now turn to the motivations underlying their investments.

According to the related literature, reviewed in Section 2, Figure 9 identifies three potential push factors, namely government support, the availability of capital to invest, and the stagnancy of the domestic market. Our survey suggests that the availability of capital to invest is a key driver for $70 \%$ of the respondents; on the contrary, just a minority of firms mentions government support (20\%), and the stagnancy of the domestic market (10\%), without remarkable differences by country of origin ${ }^{14}$.

Figure 9: Push factors of Chinese and Indian ODI in Italy

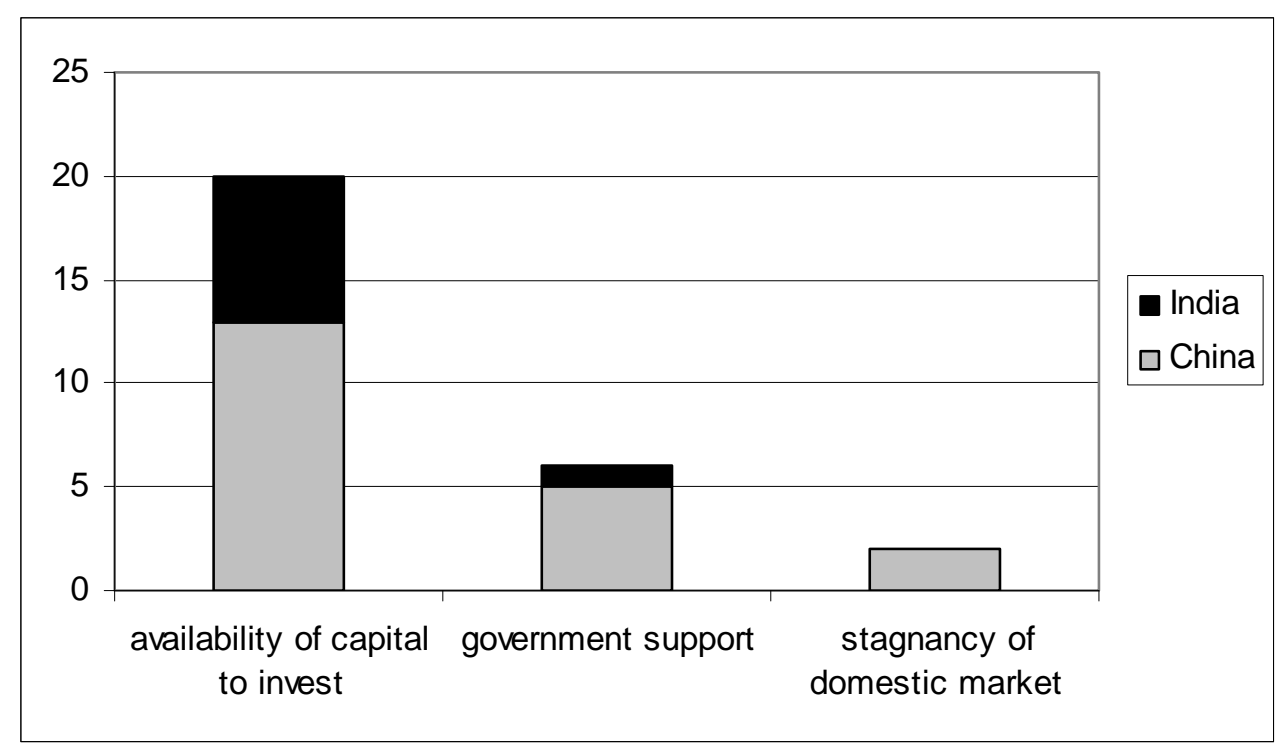

Source: author's database

Adding to pull factors, Figure 10 summarizes the main pull forces behind Chinese and Indian ODI, completing the picture about FDI motivations. Compared with Dunning (1993)'s classification of market-, resource- and efficiency-seeking considerations, we adopt a rather richer taxonomy here. Broadly speaking, the possibility to exploit Italy as

\footnotetext{
${ }^{14}$ To interpret these findings, it is worth spending a few words about the questionnaire structure. As it is mentioned in the main text, it has a multiple-choice nature, to speed up interviews and favour comparisons among respondents' answers. When multiple answers were allowed (for instance in the case of push, pull factors, main problems and future plans) firms simply selected all the interesting items listed in the questionnaire, without indicating any ranking or grading them anyhow. Of course, those items were directly inspired by the theoretical literature reviewed in Section 2, and the alternative "other" was always included to allow for more flexibility. Given this structure, the way we construct Figures 9, 10, 12 and 13 is to count all the selected items and rank them according to the most frequently answered. Having the possibility to run the survey again, we could improve our empirical findings, by asking firms to express an evaluation of each item or, at least, to give an order of importance among the selected ones.
} 
a strategic platform to Europe and the business potential belong to the first category; the availability of established brands and advanced technology, together with the abundance of high skilled labour force and specialized suppliers belong to the second, while efficiency considerations are exemplified by the possibility to avoid trade barriers. Figure 10 reveals that Chinese and Indian ODIs are mainly driven by market-seeking considerations: Italy is perceived as an important destination, both as a strategic gateway to the European continent, and because of its business potential. In addition, the hunger for intangible resources plays a key role as well, differently from efficiencyseeking motivations that are not very relevant drivers, in line with the general overview of Stanca (2009), Amighini et al. (2009a), Rabellotti and Sanfilippo (2008), Milelli and Hay (2008) and Pietrobelli et al. (2010).

Figure 10: Pull factors of Chinese and Indian ODI in Italy

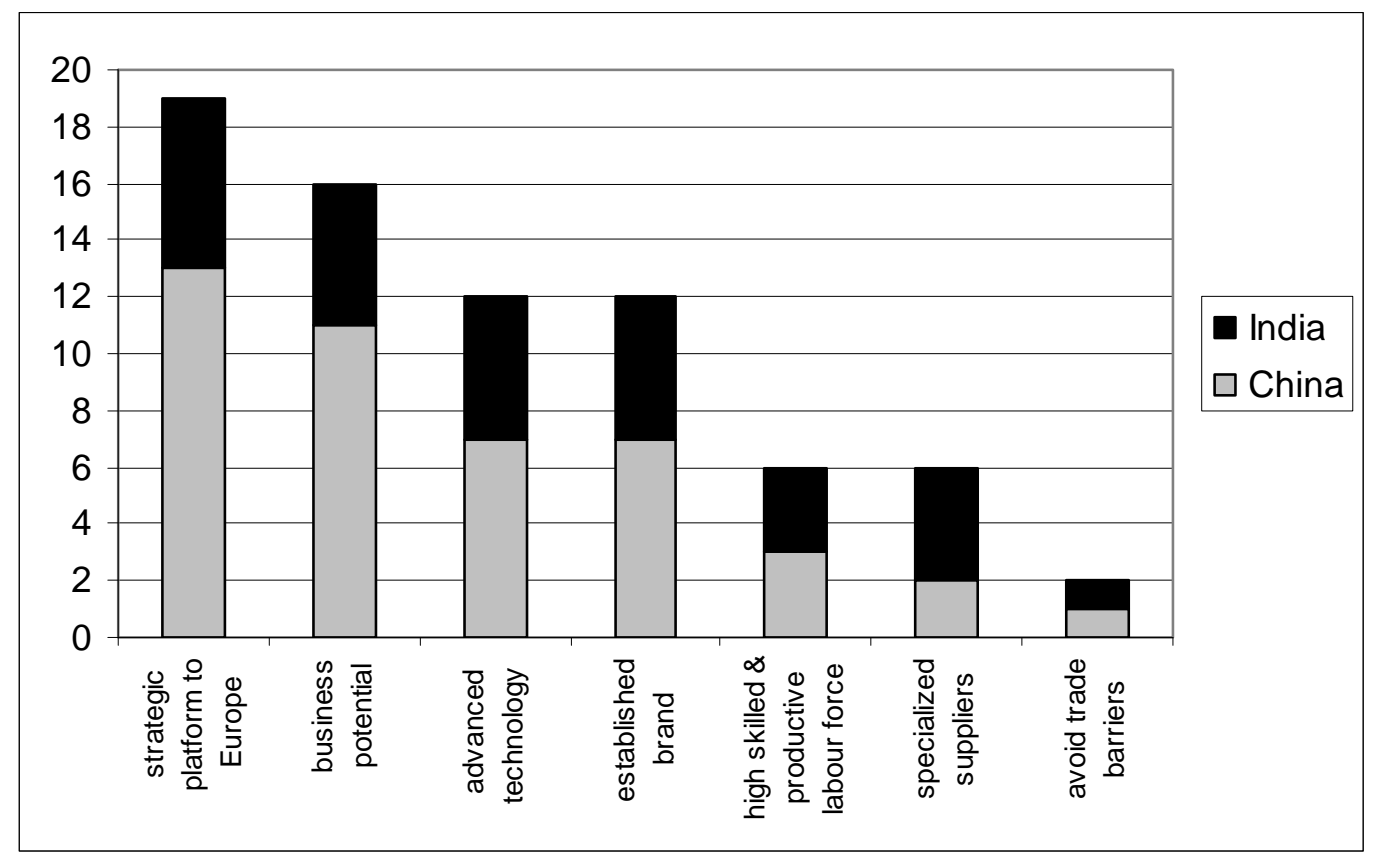

Source: author's database

\subsection{Entry modes of Chinese and Indian ODI}

As far as the entry mode is concerned, Figure 11 disaggregates Chinese and Indian ODI into merger \& acquisition, joint venture, and wholly foreign-owned enterprise. According to our survey, M\&A represents the main gate into the Italian market. Indeed, $66 \%$ of the respondents selected this mode, instead of a WFOE (17\%) or a JV (17\%). At this stage, it is worth mentioning that Chinese players entered the Italian market through 
any of the three modes, while Indian MNEs operate exclusively through merger \& acquisitions of local enterprises.

Figure 11: Entry modes of Chinese and Indian ODI in Italy

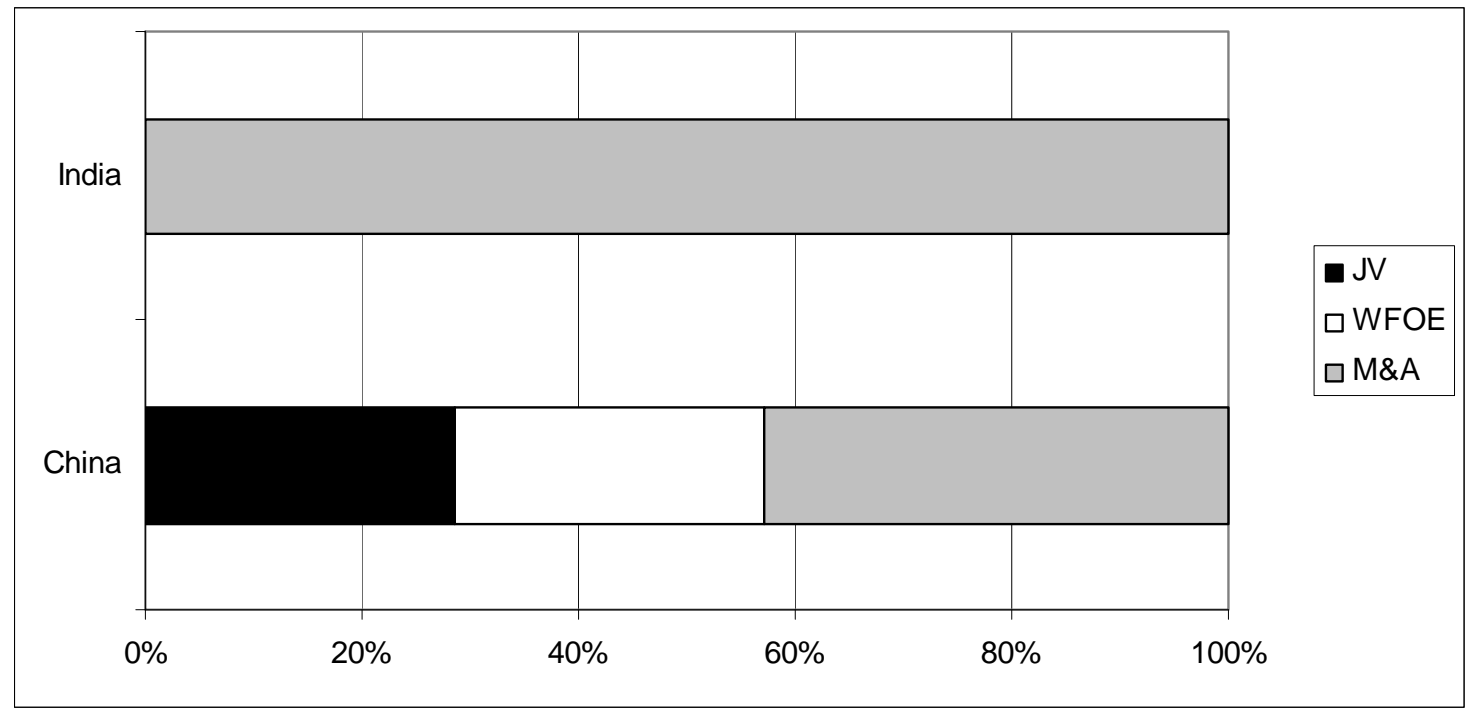

Source: author's database

These data confirm some of the predictions put forward in Madhok and Keyhani (2012) and Amighini et al. (2009a) about Chinese ODI. If past operations were usually carried on through WFOE in developing countries, present ones tend to involve M\&A and JV in developed economies. This trend is not surprising in light of the previous discussion about the type of ownership and the strategic motivations underlying foreign direct investments. Indeed, 1990s parent companies were state-owned enterprises, enjoying massive government support and driven by hunt for natural resources. On the contrary, today players are mainly private firms, used to operating in a competitive arena according to the market stimulus. This is the type of actors described in Figures 9 and 10 that invest abroad pushed by the availability of capital to invest or the stagnancy of the domestic market, and pulled by (intangible) resource-seeking considerations. Obviously, these actors prefer to operate in developed, rather than developing countries, through JV and M\&A, rather than WFOE, to maximize the possibility to gain intangible resources through intense contacts with the local enterprises.

Based on our interviews, the main arguments supporting merger \& acquisitions include cutting advertising (22\%), marketing (22\%) and manufacturing (20\%) costs, diversifying the product (16\%), smoothing potential conflicts with the local affiliate (16\%) and gaining local support (4\%). Moreover, Indian investors turn out to be 
primarily concerned with cost considerations, while Chinese ones with relational and cultural aspects ${ }^{15}$.

Differently from M\&As, wholly foreign-owned enterprises ground on the wish to strengthen own brand credibility (80\%) and to protect production secrets or intangible assets (20\%), while joint ventures are primarily motivated by the hunt for local support (40\%), technology (30\%), reputation (20\%), and the possibility to share risks and costs with an Italian partner (10\%).

\subsection{Overall evaluation of Chinese and Indian ODI}

To conclude this brief presentation of the survey results, it is worth spending a few words about the main problems faced by Chinese and Indian respondents (Figure 12) and their future plans in Italy (Figure 13). We believe this is a precious exercise to evaluate the attractiveness of the Italian market, as a FDI host, and to derive some policy implications.

Figure 12: Main problems faced by Chinese and Indian investors in Italy

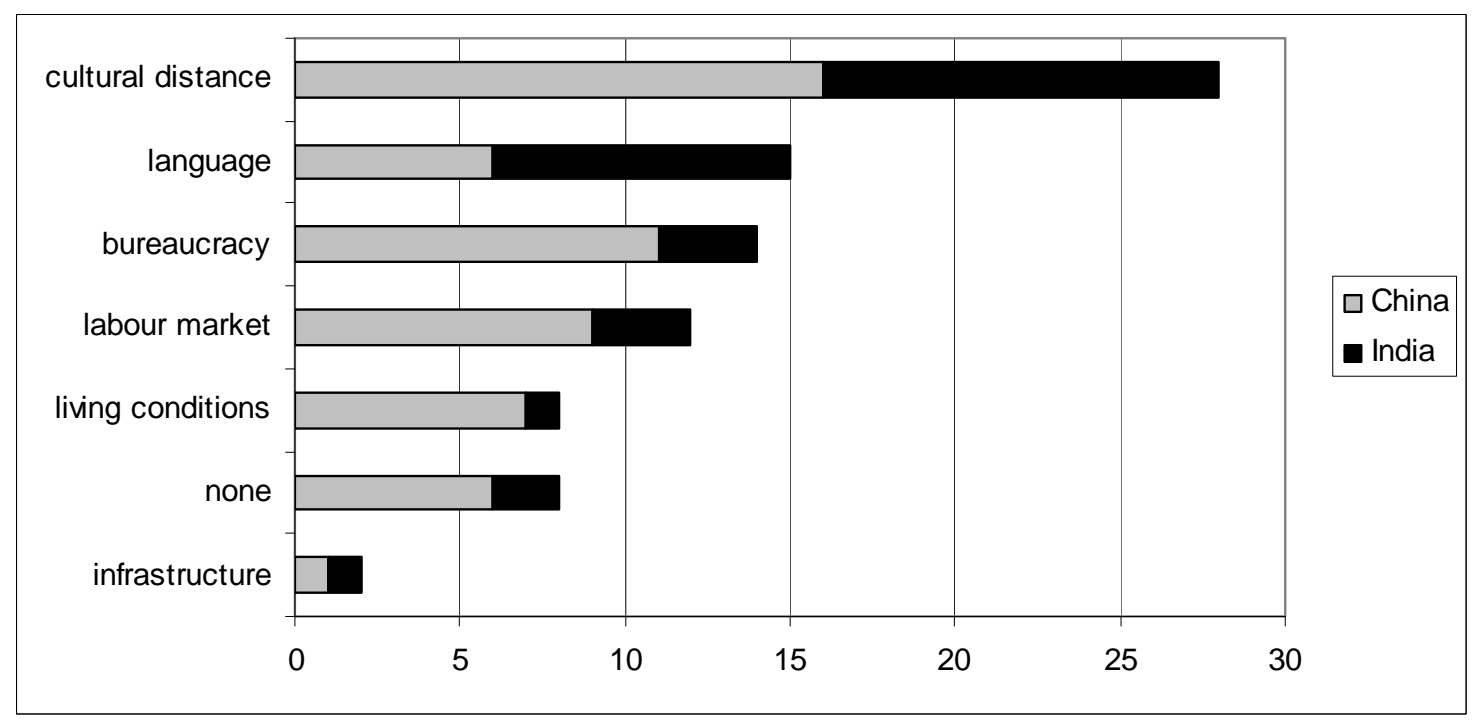

Source: author's database

Based on Figure 12, less than $10 \%$ of the sample did not face any problem in carrying the local operations. On the contrary, most firms were plagued by cultural distance (32\%), linguistic difficulties (17\%), slow bureaucracy (16\%), unfair working (14\%) or living conditions (9\%), and lack of infrastructures (2\%). At this stage, it is interesting to see that players of both nationalities substantially agree on these shortcomings however

\footnotetext{
${ }^{15}$ For more information about acquisitions by emerging countries MNEs, and their effects on the acquired firms, see Buckley et al. (2010).
} 
Dragon multinationals are primarily concerned with living conditions and Elephant MNEs with linguistic difficulties.

To better evaluate the overall satisfaction with the local operations, Figure 13 displays the surveyed investors' future plans in Italy. Data show that Chinese and Indian multinationals are quite cautious: if less than 5\% plan to exit the Italian market, the large majority simply intends to keep the current activities (53\%). Among the most optimistic, $16 \%$ is considering the possibility to invest more in already existing plants, and $27 \%$ to open new ones. Notice also that Elephant parent companies are, on average, more satisfied that their Chinese counterparts. Indeed, none of them is wishing to exit the Italian market, and half are either planning to invest more in already existing plants (8\%) or to open new ones (42\%). On the contrary, 6\% of Chinese MNEs will exit the Italian market in the near future, and only $16 \%$ intend to open new plants.

Figure 13: Future plans of Chinese and Indian investors in Italy

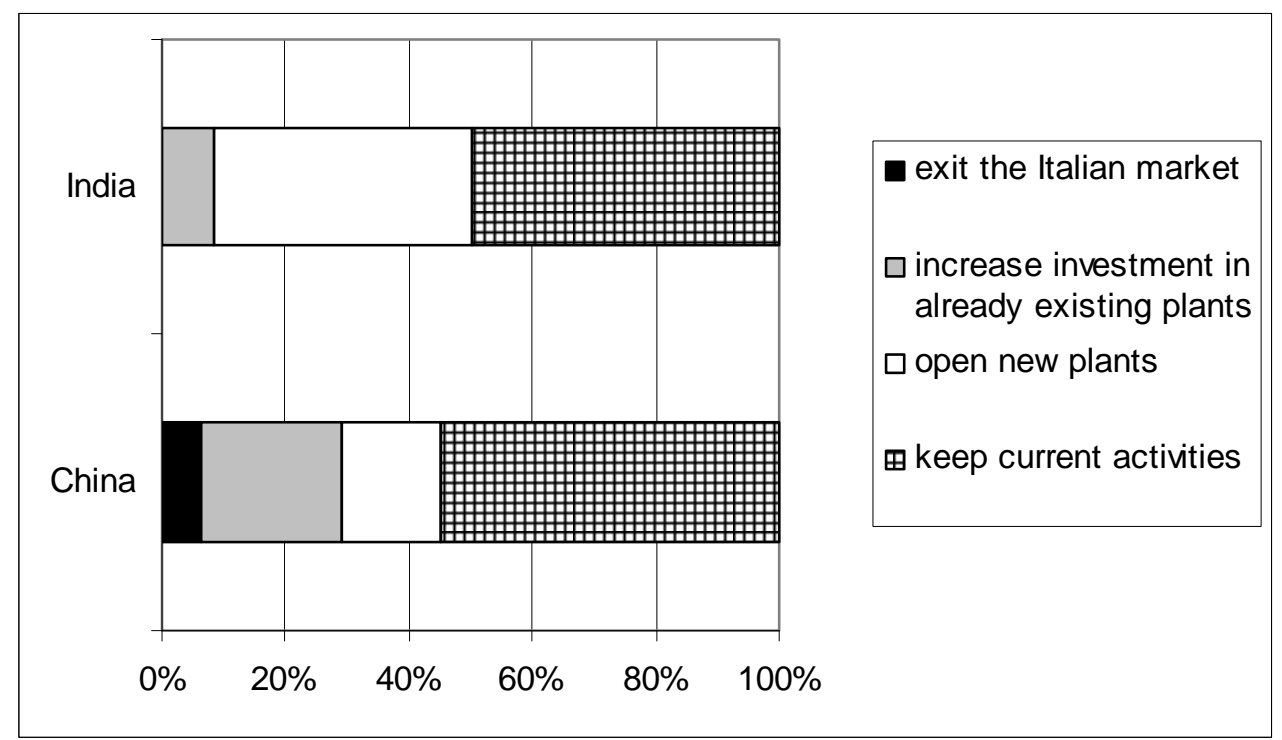

Source: author's database

\section{Conclusion}

The popularity of China and India as important recipients of FDI, over the past three decades, has been recently mirrored by their impressive performance as global investors. In particular, the Dragon and the Elephant are on the way to Europe, and on the way to Italy, which is quite an important host within the EU (Orbis, 2012) ${ }^{16}$.

\footnotetext{
${ }^{16}$ See Section 1 on this issue.
} 
This, in turn, raises interesting questions about the characteristics of Chinese and Indian investors, together with their motivations, entry mode choices, and overall satisfaction with the local operations.

The present study aims at providing an empirically documented answer to all these questions, through an original census of 50 Chinese and Indian ODIs in Italy. Data have been collected at the micro level through survey interviews, and they cover $80 \%$ of the entire population.

Our results suggest the existence of interesting analogies and differences between the Dragon and the Elephant. Analogies include parent companies' large size, low level of technology, high skilled human capital and deep international experience, adding to push, pull factors and the main problems encountered in the host market. Differences mainly involve parent companies' type of ownership, timing of investment, entry mode choice and their evaluation of the local business.

Although the present analysis is just a starting point in comparing Chinese and Indian FDIs, we believe these findings are promising enough to trigger more advanced research on the topic. If the present study suffers from data limitation, its natural extension could be an improvement in the database to allow for a more rigorous empirical exercise. To be quite honest, our data limitations are of two types, regarding the number of observations that does not allow for an econometric approach, and the number of countries involved that potentially bias results given the single host/double home nature of the study. One possible solution against these weaknesses is to extend the survey to embrace more economies receiving Chinese and Indian FDIs and/or more emerging countries adding to the Elephant and the Dragon. For instance, it would be challenging to collect data about all BRIC investors in the EU to correct both for the limited number of observations and for the country fixed effects. At the same time, having the possibility to run the survey again, it would be interesting to update the current information and potentially improve the questionnaire structure, as to better measure the multiple-choice answers. Last but not least, the survey could be thought as a starting point to identify some interesting case studies to be deeply analyzed in the future. Yet, a balanced mix between statistical analysis and case histories will certainly improve our current understanding of Chinese and Indian foreign direct investments. 
Despite these data limitations, we believe some final remarks are worth making, based on the survey results. In particular, Chinese and Indian investors' main problems and low satisfaction with the Italian experience confirm some previous concerns about the host market's capability to attract foreign direct investment, already identified in the existing literature.

As it is widely known, inward FDI is a precious vehicle of growth, given its contribution to local development through direct effects - such as training, employment and R\&D - and indirect effects - including knowledge spillover, backward and forward linkages ${ }^{17}$. However, if we look at the number of FDI projects, Italy ranks only $5^{\text {th }}$ among European most preferred hosts, after France, Germany, UK and Spain (Mariotti and Mutinelli, 2007). Moreover, there seems to be a huge gap between the potential attractiveness of the country, and its real capacity of receiving foreign direct investment. As mentioned in Basile and Mantuano (2008), Italy occupies the $29^{\text {th }}$ position worldwide in terms of potential attractiveness, but only the $112^{\text {th }}$ for the number of projects actually implemented.

Why is it the case? Our study suggests the existence of some features of the Italian marketplace that make it very appealing as a destination of foreign direct investment. They range from business potential to high skilled labour force, from the availability of intangible assets to the existence of specialized suppliers. These aspects are all stressed by Dragon and Elephant respondents and they explain why Italy is a potentially attractive host for FDI. At the same time, the surveyed enterprises systematically agree on a number of shortcomings of the Italian economy that plague multinational activity and discourage foreign direct investment. Shortcomings of this sort include bureaucracy, infrastructures and cultural distance, and they crucially affect the country's real capacity of receiving FDI.

What actions should Italy take to cope with this situation? In what follows we derive a few suggestions, based on the empirical evidence commented in Section 3. First, in our opinion, the country should take whatever action as soon as possible, since the last few years have seen an increasing competition among governments to attract FDI ${ }^{18}$. If Italy will not be proactive in the near future, it is likely to loose further positions. Second, it should possibly arrange a harmonic set of policies, organizing central and local

\footnotetext{
${ }^{17}$ For a detailed survey about direct and in direct effects of FDI see Castellani (2006).

${ }^{18}$ See Mariotti and Piscitello (2012) on this issue.
} 
initiatives in a unitary framework. This would help maximize efficiency and minimize costs, correcting for the actual overlapping of competences and proliferating of provincial agencies. Third, it should aim both at keeping current FDI and attracting new ones, as key ingredients of the above mentioned set of policies. Keeping current FDI means to support past investors and avoid them leaving the country in favour of another host. Attracting new ones requires strengthening the country's investment climate as to make it an attractive domain for future operations. If these considerations make a general sense, irrespective of the country of origin, they are particularly important if we look at emerging economies. Indeed, since they are at the early stages of their arrival in the Europe, they will presumably enlarge their presence in the future. Hence, they should be treated with special care and any effective FDI attraction policy should be at least partially tailored on their specificities and needs. Moreover, as commented in 3.2, ethnic networks play an important role in orienting emerging countries operations since they tend to cluster around a well established community of expatriates. Thus, in the case of Chinese and Indian FDI, keeping current investments and attracting new ones go at the same pace. Put another way, if Italy succeeds in enhancing its reputation towards current investors it is very likely to encourage new ones in setting local subsidiaries. This is a precious opportunity the country should definitely take.

How? We suggest paying particular attention at the weaknesses identified by the surveyed enterprises, namely bureaucracy, infrastructures and cultural distance. In our opinion, they are particularly stressed by Chinese and Indian respondents since problems of the same sort plague their domestic economies as well, making them suffer from a severe liability of emergingness (Madhok and Keyhani 2012). If Italy succeeds in healing its diseases, making Dragon and Elephant MNEs feel comfortable in investing there, it will probably be rewarded by a steadily increasing presence of multinational enterprises from the two countries.

In the respondents' answers, the main problem with bureaucracy rests with visas. It seems extremely hard to get them for Chinese and Indian workers employed in Italy and wishing to spend some time in their native countries, for instance during holidays. The process is so lengthy and intricate that some local affiliates even decided to hire dedicated personnel to take care of it. This is something the policy maker should definitely consider, in order to ease and speed up the entire procedure. 
Adding to bureaucracy, the lack of (social) infrastructures is another major complain of Chinese and Indian firms that are concerned with the living conditions of their expatriates. For instance, international schools are quite rare in the whole country, which makes it difficult for Chinese and Indian employees to bring children with them. This, in turn, discourages foreign presence of people with families. Moreover, our survey documents that it is hard to get a bank account and to deal with people in general since English is still spoken by a minority of the population, even in the information desks, hospitals and public counters. Last but not least, cultural distance is lamented by a notable group of respondents, suggesting that Italy is still perceived as a difficult and faraway country. This aspect is closely related to the previous one, since improving mutual understanding certainly passes through communication, but communication is rather impossible if (at least) English is not widely spoken. Notice also that the negative reaction of the public opinion often exacerbates this problem, inducing expatriates to live within their own community. To partially alleviate this problem, we believe the Italian government should try to integrate the foreign population as much as possible with the natives. This could be achieved with simple initiatives such as managing adequate training for young graduates in Chinese and Indian studies, promoting common cultural events with music, arts and food, and providing some intercultural sessions on foreign literature, history and traditions as part of the primary and secondary school programmes. Doing this way, Italian people will have the chance to know Chinese and Indian players more and form their own opinion independently from common biases. This would surely enhance mutual understating which is quite a valuable task, with or without FDI plans.

\section{References}

Amighini A., Chiarlone S. 2007. La trasformazione dell'economia cinese: proprietà dell'impresa e modello di specializzazione. Economia e Politica Industriale, 3: 185200.

Amighini A., Rabellotti R., Sanfilippo M. 2009a. Gli investimenti cinesi in Europa ed in Itala. Mondo Cinese, January-June: 138-139.

Amighini A., Rabellotti R., Sanfilippo M. 2009b. The Rise of Multinationals from emerging Countries. A Review of the Literature. Emerging Economic Regional Powers 
and Local Systems of Production: New Threats or New Opportunities? Working Paper Series, 4.

Athreye S., Kapur S. 2009. Introduction: The Internationalization of Chinese and Indian Firms - Trends, Motivations and Strategy. Industrial and Corporate Change, 18 (2): 209-221.

Athukorala P. 2005. Outward direct investment from India. Australian National University, Department of Economics Working Paper, 14.

Basile R., Mantuano M. 2008. L'attrazione di Investimenti Diretti Esteri in Italia e nel Mezzogiorno: il ruolo delle politiche nazionali e regionali. L'Industria, 29 (4): 623-642.

Becattini G. 1998. Distretti industriali e made in Italy. Bollati Boringhieri: Firenze .

Berger, B., Berkofsky A. 2008. Chinese Outward Investments: Agencies, Motives and Decision-Making, CASCC Briefing Paper, 172.

Buckley P.J., Clegg L.J., Cross A.R., Liu X., Voss H., Zheng P. 2007. The Determinants of Chinese Outward Foreign Direct Investment. Journal of International Business Studies, 38 (4): 499-518.

Buckley P.J., Cross A.R., Voss H. 2008. Chinese Direct Investment in the United Kingdom: An Assessment of Motivations and Competitiveness, paper presented at the conference «Corporate Strategies in the New Asia», 1-2 Feb 2008, University of Bremen, UK.

Buckley P.J., Elia S., Kafourus M. 2011. FDI from emerging to advanced countries: some insights on the acquisition strategies and on the performance of target firms. Economia e Politica Industriale, 38 (1): 181-197.

Castellani D. (2006), L’impatto della presenza delle imprese multinazionali sul contesto locale, in Mariotti S., Piscitello L. (eds) Multinazionali, innovazione e strategie per la competitività. Il Mulino: Bologna.

Child J., Rodrigues B. 2005. The Internationalization of Chinese Firms: A Case for Theoretical Extension?. Management and Organization Review, 1 (3): 381-410.

Cui L., Jiang F., Stening B.W. 2008. Determinants of FDI Entry Mode Decisions of Chinese MNCs, paper presented at the conference «AIBAIB Annual Meeting», 30 June3 July 2008, Milano, Italy.

Deng P. 2007. Investing for Strategic Resources and its Rationale: The Case of Outward FDI from Chinese Companies. Business Horizons, 50: 71-81. 
Dunning J.H. 1993. Multinational Enterprises and the Global Economy, Addison Wesley: Wokingham.

Duysters G., Jacob J., Lemmens C., Jintian Y. 2009. Internationalization and Technological Catching Up of Emerging Multinationals: a Comparative case Study of China’s Haier Group. Industrial and Corporate Change, 18 (2): 325-349.

Fortainer F., van Tulder R. 2009. Internationalization Trajectories - a Cross-Country Comparison: Are Large Chinese and Indian Companies Different?. Industrial and Corporate Change, 18 (2): 223-247.

Giovannetti G., Mazzeo E. 2008. Struttura industriale e competitività: elementi determinanti nel processo di internazionalizzazione dell'economia italiana. L'Industria, 29 (1): 117-133.

Goldstein A. 2006. Le multinazionali delle economie emergenti. Economia e Politica Industriale, 1: 161-174.

IMF 1993. Balance of Payments Manual 5th Edition. IMF: Washington DC.

Kumar N. 2008. Internationalization of Indian enterprises: patterns, strategies, ownership advantages and implications. Asian Economic Policy Review, 3 (2): 242-261. Kumar N., Chadha A. 2009. India's Outward Foreign Direct Investments in Steel Industry in a Chinese Comparative Perspective. Industrial and Corporate Change, 18 (2): 249-267.

Luo Y., Tung. R.L. 2007. International Expansion of Emerging Market Enterprises: A Springboard Perspective. Journal of International Business Studies, 38 (4): 481-498.

Madhok A., Keyhani M. 2012. Acquisitions as entrepreneurship: Asymmetries, opportunities, and the internationalization of multinationals from emerging economies. Global Strategy Journal, 2 (1): 26-40.

Mariotti S., Mutinelli M. 2007. L'Italia nella nuova geografia degli investimenti diretti esteri. Economia e Politica Industriale, 1: 125-140.

Mariotti S., Mutinelli M. 2008. Le multinazionali dei paesi emergenti in Italia. Economia e Politica Industriale, 1: 181-187.

Mariotti S. 2009. Tendenze degli investimenti diretti esteri dopo la crisi finanziaria: che accade?. Economia e Politica Industriale, 3: 123-131.

Mariotti S., Piscitello L. 2012. Linee guida per un’efficace politica di attrazione degli investimenti esteri. Economia e Politica Industriale, 39 (1): 139-157. 
Milelli C., Hay F. 2008. Chinese and Indian firms’ entry into Europe: Characteristics, impacts and policy implications. Université Paris X Nanterre Economix Working Paper 35.

Nicolas F., Thomsen S. 2008. The Rise of Chinese Firms in Europe: Motives, Strategies and Implications, paper presented at the conference «Research Workshop on Chinese Investment in Europe», 17 Sept 2008, Chatham House, London, Regno UK.

Nicolas F. 2009. Facts and Fallacies about Chinese Direct Investment in Europe. Chatham House Briefing Paper, June.

Niosi J., Tschang F.T. 2009. Strategies of Chinese and Indian software multinationals: implications for internationalization theory. Industrial and Corporate Change, 18 (2): 269-294.

ORBIS 2012. Orbis: a world company information, at http://lib.unibocconi.it/*ita Pietrobelli C., Rabellotti R., Sanfilippo M. 2010. The "Marco Polo” Effect: Chinese FDI in Italy. Journal of Technology and Globalization, 4 (4): 277-291.

Pradhan J.P., Aggarwal R. 2011, On the globalness of emerging multinationals: a study of Indian MNEs. Economia e Politica Industriale, 38 (1): 163-180.

Rabellotti R., Sanfilippo M. 2008. Chinese FDI in Italy, lavoro presentato alla conferenza «Research Workshop on Chinese Investment in Europe», 17 Settembre 2008, Chatham House, Londra, Regno Unito.

Rajan R.S. 2009. Outward foreign direct investment from India: trends, determinants and implications. ISA Working Paper, 66.

Ramapurti R., Singh J.V. 2009. Indian multinationals: generic internationalization strategies, in Ramapurti R., Singh J.V. (Editors) Emerging multinationals in emerging markets. Cambridge University Press: Cambridge.

Schuller M., Turner A. 2005. Global Ambitions: Chinese Companies Spread their Wings. China Aktuell-Journal of Current Chinese Affairs, 4: 3-14.

Singh L., Jain V. 2009. Emerging patterns of India's outward foreign direct investment under the influence of state policy: a macro view. Punjabi University, mimeo.

Spigarelli M. 2009. Le multinazionali dei paesi emergenti: gli investimenti cinesi in Italia. Economia e Politica Industriale, 2: 131-159.

Stanca L. 2009. Investimenti diretti cinesi in Italia: da ruscello a fiume?. Economia $e$ Politica Industriale, 1: 135-144. 
UNCTAD 2006. World Investment Report, Geneva at www.unctad.org.

UNCTAD 2012. World Investment Report, Geneva at www.unctad.org.

Wei Y., Wang C. 2009. Understanding China's international economic integration. Journal of Chinese Economic and Business Studies, 7 (4): 401-408.

Yeung H.W., Liu W. 2008. Globalizing China: the rise of mainland Chinese firms in the global economy. Eurasian Geography and Business Studies, 8 (2): 117-132.

Yiu, D.W., Lau C.M., Bruton G.D. 2007. International Venturing by Emerging Economy Firms: the Effects of Firm Capabilities, Home Country Networks, and Corporate Entrepreneurship. Journal of International Business Studies, 38 (4): 519-540. Yueh L. 2010. Thirty years of legal and economic reform in China: growth, institutions, and laws. Journal of Chinese Economic and Business Studies, 8 (2): 117-132.

Zhang K. 2005. The Why, Where and How of Chinese Companies Outward Investment Intentions. Asia Pacific Foundation of Canada, 5: 1-36.

Zhang W., Liu X. 2009. Success and challenges: an overview of china's economic growth and reform since 1978. Journal of Chinese Economic and Business Studies, 7 (2): 127-138. 